\title{
The effects of thinning on carbon stocks and fluxes in a Chinese arborvitae plantation
}

\author{
by Liang Fang ${ }^{1}$, Jia Zhongkui ${ }^{1, *}$ and Ma Lvyi ${ }^{1}$
}

\begin{abstract}
China has extensive areas of forest plantations that sequester and store large quantities of carbon. However, the rate of carbon sequestration by Chinese arborvitae (Platycladus orientalis Linn. Franco) is unknown. This research looks at carbon stocks and fluxes in forest vegetation, soil and litter seven years after thinning Chinese arborvitae in order to evaluate the effect of thinning levels on carbon sequestration. At 22 years, the plots were reduced from 5900 to 4100 and 3000 trees per hectare in three replicates. Carbon stocks of above-ground tree materials were lowest in the heaviest thinned plots and highest in the control plots. Above-ground shrub carbon pools were the opposite, i.e., largest in the heaviest thinned plots and lowest in the controls. Soil and litter carbon stocks were not affected by thinning treatment. Results suggest that thinning may positively affect vegetation carbon sequestration in the short term, an important observation for forest managers using thinning to optimize carbon sequestration capacity.
\end{abstract}

Key words: forest management, carbon sequestration, warm-temperate forest, soil respiration

\section{Résumé}

La Chine comporte de vastes étendues de plantation forestière qui captent et emmagasinent de grandes quantités de carbone. Cependant, le taux de séquestration du thuya de Chine (Platycladus orientalis Linn. Franco) nest pas connu. Cette étude porte sur les stocks et les flux de carbone dans la végétation forestière, le sol et la litière sept ans après une éclaircie réalisée dans un peuplement de thuya de Chine afin dévaluer les effets de léclaircie sur la séquestration du carbone. Les parcelles localisées dans des peuplements de 22 ans ont été éclaircies pour réduire le nombre d’arbres par hectare de 5900 à 4100 et 3 000, dans un dispositif à trois répétitions. Les stocks de carbone de la partie épigée des arbres étaient les plus faibles dans les parcelles les plus éclaircies et les plus élevés dans les parcelles témoins. Les stocks de carbone de la partie épigée des arbustes se sont comportés à l'inverse, c’est-à-dire, les plus élevés dans les parcelles les plus éclaircies et les plus faibles dans les parcelles témoins. Les stocks de carbone dans le sol et la litière n’ont pas été influencés par léclaircie. Les résultats suggèrent que l'éclaircie pourrait affecter de façon positive le stockage du carbone dans la végétation à court terme, une constatation importante pour les aménagistes forestiers qui utilisent léclaircie pour optimiser la capacité de séquestration du carbone.

Mots clés : aménagement forestier, séquestration du carbone, forêt tempérée chaude, respiration des sols

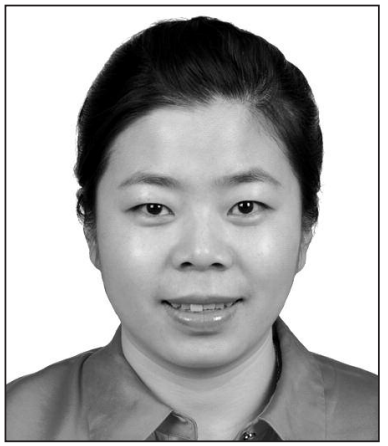

Liang Fang

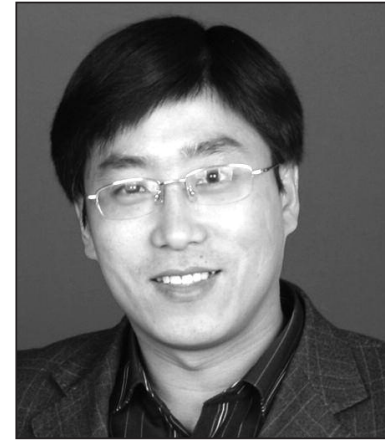

Jia Zhongkui

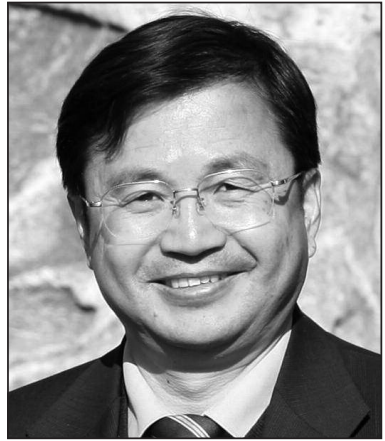

Ma Lvyi

\footnotetext{
${ }^{1}$ Department of Silviculture and Conservation, Beijing Forestry University, China

${ }^{\star}$ Corresponding author. E-mail: jiazk@bjfu.edu.cn
} 


\section{Introduction}

Detailed investigation of current carbon stock levels and sequestration potentials is required to understand the role of China's plantations in global carbon dynamics (Valentini et al. 2000, Hudiburg et al. 2009). In order to optimize forest carbon sequestration, it would be particularly beneficial to determine if specific management practices can modify carbon stocks of important tree species.

For instance, thinning as a management tool has been widely utilized to manipulate stand growth and timber yield (Hoover and Stout 2007). Thinning a densely stocked stand reduces its carbon stock and turns it into an atmospheric source of carbon initially (Dore et al. 2010), but it may gradually turn into a carbon sink with the rapid growth and enhanced photosynthesis of remaining trees. Thinning may influence overall ecosystem carbon sequestration by not only affecting tree growth but also microclimatic environments within the plantation, which alter soil $\mathrm{CO}_{2}$ flux rates. In addition, thinned plantations are less vulnerable to wildfire (as fuel on the ground has been reduced), preventing carbon emissions through burning (Finkral and Evans 2008, Hurteau et al. 2008). Further, as a silvicultural tool, thinning has been widely used to moderate competition in favor of species/individuals of interest to increase tree production (Liu et al. 1992) and resistance to pests (Coyea and Margolis 1994), thereby achieving a more mature and stable forest structure within a shorter time period (Vargas et al. 2009).

Chinese arborvitae is a regionally representative species of the warm-temperate coniferous forests of China. Plantations of this species in the greater Beijing area cover about $26 \%$ (State Forestry Administration 2007). It is one of the most important species used for reforestation and afforestation in this region. The species is widely distributed as it tolerates nutrient deficiency and drought (Feng et al. 1999). As such, Chinese arborvitae offers a unique opportunity to test climate change mitigation through forest management practices.
It is well known that the productivity of Chinese arborvitae plantations may be greatly enhanced through thinning (Duan et al. 2010). Previous studies of these plantations identified management steps for optimal stand growth (Duan $e t$ al. 2010). However, the effects of thinning on carbon storage and fluxes are sparsely represented in the literature, but are in high demand to contribute to the knowledge base needed for enhanced forest carbon sequestration through management strategies. This paper reports on the effects of thinning of Chinese arborvitae plantations in the northern surburbs of Beijing seven years after treatment.

\section{Methods}

\section{Study area}

The research was conducted in 28-year-old plantations of Chinese arborvitae in the Shisanling area of Beijing (Fig. 1.). The site is a southeast-facing slope of $20 \%$ at an elevation of $900 \mathrm{~m}$. It is under a temperate continental monsoon climate with a mean annual temperature of $4.8^{\circ} \mathrm{C}$, an average annual precipitation of $610 \mathrm{~mm}$ and an average relative humidity of $66 \%$. The soil is alluvial with a $\mathrm{pH}$ of 6.6 to 7.2 and $17 \%$ to $21 \%$ organic matter. The understory includes mountain-ash (Sorbus pohuashanensis [Hance.] Hedl.), honeysuckle (Lonicera japonica Thunb.), hazelnut (Corylus mandshurica Maxim.), spiraea (Spiraea trilobata Linn.), bushclover (Lespedeza bicolor Turcz.), painted maple (Acer mono Maxim.) and vervain (Vitex negundo Linn. var. heterophylla [Franch.] Rehd.).

\section{Experimental design}

Thinning treatments were based on different management objectives and resource availability in April 2004. The original density was 5900 trees per ha. Two thinnings were carried out to reduce stands to 4100 trees per ha (N4100 treatment) and 3000 trees per ha (N3000 treatment). The control of 5900 trees per ha was not thinned. The N4100 and N3000 treat-

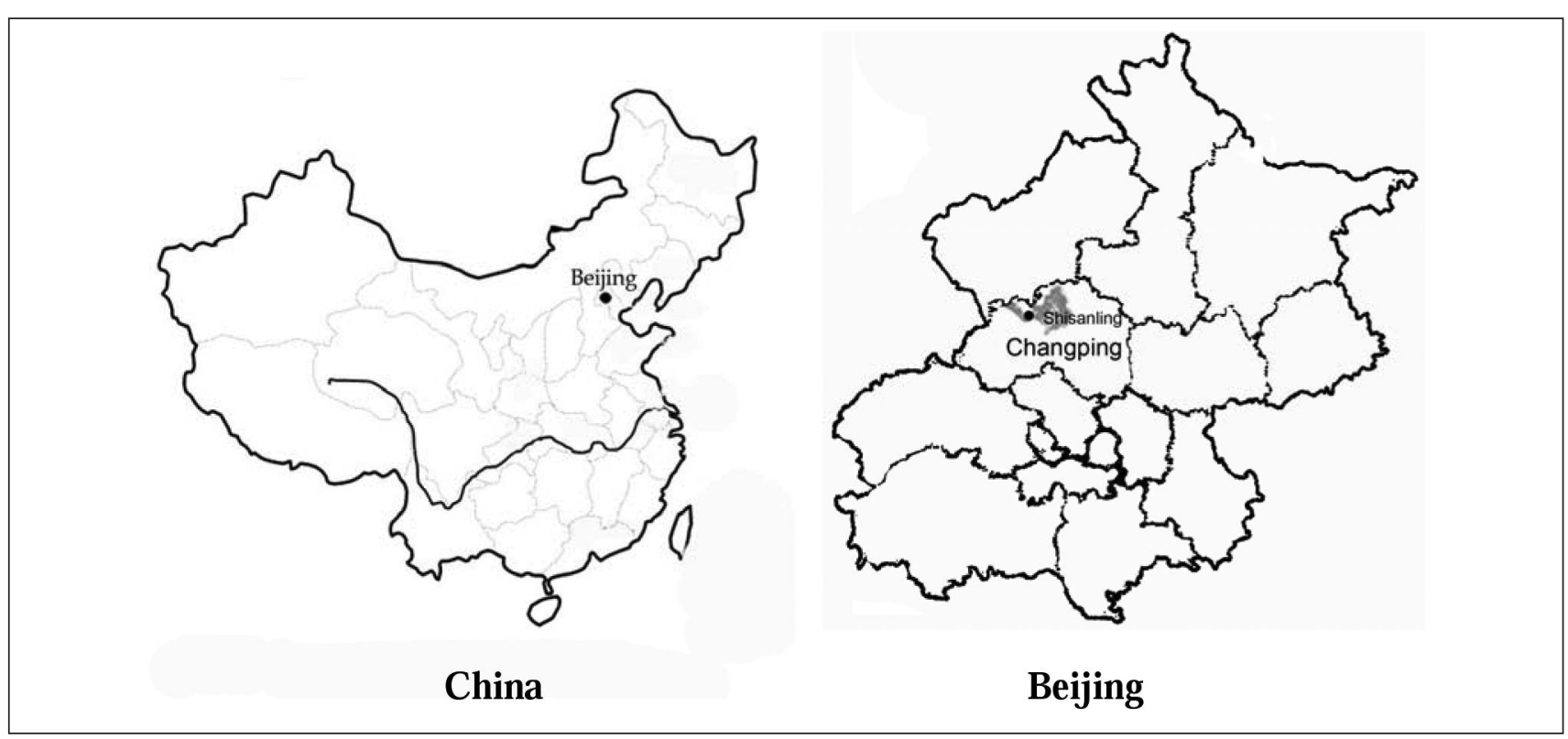

Fig. 1. The site was located in the Changping area of northwestern Beijing (black circle) at 900 metres elevation, shown within the greater Shisanling ecoregion (shaded area) 
ments represent the early rotation period and the late thinning, respectively, for this species. Plots were divided into three treatments and three replications. Each of the nine plots was 0.1 ha with a $20 \mathrm{~m}$ aisle between plots. The placement of each plot within the plantation was arbitrary and only established to avoid edge influence. Large slash piles were removed after thinning and the stands remained intact. Information on tree characteristics at the time of the first stand measurement in 2005 (one year after thinning) are summarized in Table 1.

Table 1. Stand characteristics (mean values [S.D.]) in 2005

\begin{tabular}{lcccc}
\hline & $\begin{array}{c}\text { Average } \\
\text { height } \\
\mathbf{( m )}\end{array}$ & $\begin{array}{c}\text { Basal area } \\
\left(\mathbf{m}^{-\mathbf{2}} \mathbf{h a} \mathbf{- 1}\right)\end{array}$ & $\begin{array}{c}\text { Canopy } \\
\text { height } \\
\mathbf{( m )}\end{array}$ & $\begin{array}{c}\text { Standing } \\
\text { volume } \\
\left(\mathbf{m}^{\mathbf{3}} \mathbf{h a} \mathbf{- 1}\right)\end{array}$ \\
\hline Control & $6.07 \pm 0.67$ & $19.83 \pm 1.31$ & $4.28 \pm 0.69$ & 61.91 \\
N4100 & $6.50 \pm 0.40$ & $16.02 \pm 2.01$ & $4.75 \pm 0.33$ & 45.82 \\
N3000 & $5.68 \pm 0.78$ & $12.44 \pm 1.82$ & $4.32 \pm 0.50$ & 34.14 \\
\hline
\end{tabular}

\section{Biomass estimation}

Height and diameter at breast height $(\mathrm{DBH})$ were recorded yearly for all trees with a $\mathrm{DBH}>3 \mathrm{~cm}$ in each plot at the end of each growing season in 2011. Standing volume including bark was calculated with volume functions (Chen et al. 1986). Tree biomass for each plot was determined using species-specific allometric equations based on tree height and $\mathrm{DBH}$ (Chen et al. 1986). Tree biomass (including stems, branches and bark), foliage and coarse roots $>1 \mathrm{~cm}$ diameter were used. The total biomass for each plot was determined by adding all compartments for all trees. Average carbon content was approximately $50 \%$.

The volume of dead wood (snags) and stumps (DBH $>2.5$ $\mathrm{cm}$ ) were determined and their biomass calculated. Average density of woody debris was determined by weighing and dividing this value using water volume displaced (Tang et al. 2003). Average carbon content was around 50\%.

Ten subplots $(2 \mathrm{~m} \times 2 \mathrm{~m})$ were randomly selected from each plot to determine understory (hereafter referred to as shrubs) biomass for wood and foliage in 2011. All samples were harvested and used to measure biomass after oven-drying at $75^{\circ} \mathrm{C}$ for three days. The carbon fraction was estimated using a conversion factor of 0.50 based on carbon analyses (Fang et al. 2007).

\section{Soil sampling}

Fine roots ( $\leq 1 \mathrm{~cm}$ diameter) present in the top $20 \mathrm{~cm}$ of soil were sampled by using soil cores $(7.5 \mathrm{~cm}$ diameter). In each plot, 15 regularly spaced soil core samples were taken each month from May to September in 2011. Fine roots were manually isolated from the sampled mineral soil cores, rinsed free of organic matter with deionized water and oven-dried at $70^{\circ} \mathrm{C}$ to determine dry weight. Fine roots of each plot were estimated using a modified maximum and minimum root core method (McClaugherty et al. 1982). Additionally, the forest floor was sampled at 15 points within each plot by soil coring (5.5 cm diameter). All samples were dried at $75^{\circ} \mathrm{C}$ for three days and weighed. Oven-dried forest floor masses were converted to carbon using a factor of 0.5 (Law et al. 2001).
Within the plantations, five soil profiles for each plot were randomly located to cover possible variations of soil properties. Soil bulk density was sampled from each soil horizon (10 $\mathrm{cm}$ for each horizon, for a total of seven horizons). Mineral soil carbon content down to $70 \mathrm{~cm}$ was calculated in terms of bulk density and organic matter content was measured using the wet digestion method. Soil organic carbon stocks were estimated from organic matter using a factor of 0.58 (Fang et al. 2007).

\section{Litter collection}

In May 2010, five litter collectors were placed randomly within each plot in a regular pattern $(1 \mathrm{~m} \times 1 \mathrm{~m})$. The collectors were square-shaped with wooden poles $0.5 \mathrm{~m}$ above the ground. Growing season litterfall was collected each month, while winter litterfall was collected once every two months. The last litter collection was made December 2011. One year's litter was collected from autumn 2010 to autumn 2011. The litter was dried at $75^{\circ} \mathrm{C}$ for three days and weighed. The ovendried biomass was converted to carbon using a factor of 0.5 (Law et al. 2001).

\section{Soil respiration}

Soil respiration rate (Rs) was measured using a LiCor-6400 portable infrared gas analyzer coupled to a LiCor-6400-09 soil respiration chamber (LiCor Biosciences, Lincoln, NE, USA) for data collection and storage. Ground vegetation was removed before measurement in order to minimize disturbance. During measurements, the chamber sat on permanently installed PVC collars (10 cm diameter, $5 \mathrm{~cm}$ height) inserted $3 \mathrm{~cm}$ into the ground at least 20 days before measurement to ensure that the soil had recovered from the disturbances. For each plot, soil respiration was measured monthly at 10 points from May to September in 2011. On each occasion, all 120 spots were measured on three or four rain-free days to minimize effects of diurnal fluctuation. Soil temperature (Ts) and soil water content (Ms) near the chamber at 10 $\mathrm{cm}$ depth below ground was measured simultaneously with the Rs with a 6400 temperature probe (LiCor Biosciences, Lincoln, NE, USA) and a time domain reflectometer system (TDR, CS615 Campbell scientific, Logan, UT, USA).

\section{Statistical analysis}

For the Rs measurements, there were five samples within each plot and calculated based on average daily values each month. The thinning treatments effect on various carbon pools and Rs were tested using the interaction term of replicate and treatment as random error (ANOVA). If the effects of treatments were significant, means were further compared by Duncan's multiple range tests with a confidence level of $P<0.05$. All tests were performed using SPSS v10.0 statistical software (SPSS Inc., Chicago, IL, USA). The Rs of repeated measurements in the same occasion was analysed in SPSS to assess the effect of time during the growing season.

\section{Results}

\section{Carbon stock assessment}

Wood (stem + branch) and foliage carbon stocks in the N4100 plots were some 74\% of control plots, determined by above-ground tree carbon pools (Table 2). Similarly, total above-ground tree carbon pools were $54 \%$ of control plots in 


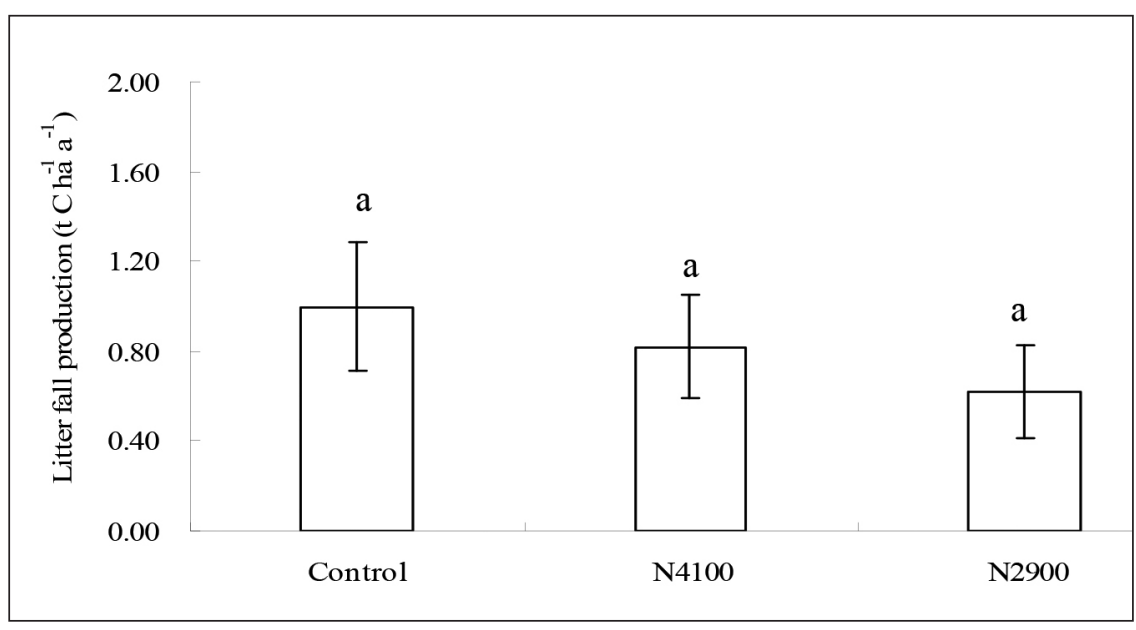

Fig. 2. Litter production during one year.

Table 2. Distribution of tree and shrub carbon pools (t ha-1 $]$ - mean values and [S.D.]

\begin{tabular}{lrrr}
\hline & \multicolumn{3}{c}{ Treatment } \\
\cline { 2 - 4 } Item & \multicolumn{1}{c}{ Control } & \multicolumn{1}{c}{ N4100 } & \multicolumn{1}{c}{ N3000 } \\
\hline Tree-stem (including bark) & $20.42 \mathrm{~b}(10.30)$ & $15.03 \mathrm{a}(6.05)$ & $11.12 \mathrm{a}(5.60)$ \\
Tree branches & $11.00 \mathrm{~b}(4.71)$ & $8.30 \mathrm{a}(3.09)$ & $5.69 \mathrm{a}(2.32)$ \\
Tree foliage & $9.15 \mathrm{~b}(2.37)$ & $6.44 \mathrm{a}(2.15)$ & $5.17 \mathrm{a}(1.61)$ \\
Shrub-branches & $0.74 \mathrm{~b}(0.23)$ & $1.00 \mathrm{a}(0.19)$ & $1.24 \mathrm{a}(0.31)$ \\
Shrub-foliage & $0.16 \mathrm{~b}(0.05)$ & $0.42 \mathrm{a}(0.06)$ & $0.59 \mathrm{a}(0.09)$ \\
Coarse root $(\mathrm{R}>2 \mathrm{~cm})$ & $10.80 \mathrm{~b}(4.02)$ & $9.51 \mathrm{ab}(2.86)$ & $7.80 \mathrm{a}(2.04)$ \\
Fine root $(\mathrm{R}>2 \mathrm{~cm})$ & $0.0150 \mathrm{a}(0.08)$ & $0.0124 \mathrm{a}(0.04)$ & $0.0120 \mathrm{a}(0.05)$ \\
Stumps & $3.66 \mathrm{~b}(0.84)$ & $2.73 \mathrm{a}(0.93)$ & $2.06 \mathrm{a}(0.68)$ \\
Sum & $55.95 \mathrm{~b}(23.61)$ & $43.44 \mathrm{a}(15.37)$ & $33.68 \mathrm{a}(12.71)$ \\
\hline
\end{tabular}

Figures with different letters are significantly different ( $5 \%$ level). Respiratory fluxes are presented as the average of periodic measurements during the growing time in 2011 and were largely conserved between treatments.

Table 3. Soil carbon stocks and forest floor mass $\left(t \mathrm{ha}^{-1}\right)-$ mean values and (S.D.)

\begin{tabular}{lcrr}
\hline & \multicolumn{3}{c}{ Treatment } \\
\cline { 2 - 4 } Item & Control & \multicolumn{1}{c}{$\mathbf{N 4 1 0 0}$} & \multicolumn{1}{c}{ N3000 } \\
\hline Soil carbon stocks & $52.52 \mathrm{a}(6.40)$ & $53.32 \mathrm{a}(8.34)$ & $46.50 \mathrm{a}(6.43)$ \\
Forest floor layer & $17.28 \mathrm{a}(3.14)$ & $18.81 \mathrm{a}(2.81)$ & $23.34 \mathrm{a}(4.84)$ \\
Sum & $69.80 \mathrm{a}(9.54)$ & $72.14 \mathrm{a}(11.15)$ & $69.84 \mathrm{a}(11.27)$ \\
\hline
\end{tabular}

Figures with different letters are significantly different ( $5 \%$ level). Respiratory fluxes are presented as the average of periodic measurements during the growing time in 2011 and were largely conserved between treatments.

ecosystem-level wood : root : foliage biomass ratios were $60: 25: 15$ among all treatments. The conservation of components at the ecosystem level was afforded by the shrubs on these plots having only marginally higher foliage fractions than the trees $(0.31$ and 0.19 for shrubs and trees, respectively).

\section{Litter production}

No significant effect of thinning was found on litter production over a oneyear period (Fig. 2). Decreased amounts of litter were noted in treated plots. The difference between the control plots and the N3000-treated plots was about $0.22 \mathrm{t} \mathrm{C} \mathrm{ha}^{-1} \mathrm{a}^{-1}$.

Soil carbon stocks and forest floor Table 3 shows the carbon stocks of forest floor and soil down to $70 \mathrm{~cm}$. There were no significant effects of treatment shown in any soil layers.

\section{Soil respiration}

Daytime Rs during the growing season averaged 2.8, 4.5, and $3.5 \mu \mathrm{mol}$ $\mathrm{CO}_{2} \mathrm{~m}^{-2} \mathrm{~s}^{-1}$ in the control, N3000 and N4100 treatment plots respectively (Table 4). No significant variation was observed in the treatments effect as well as measurement time (occasion). The seasonality of soil respiration was similar across all treatments. The lowest soil respiration occurred in the control plots while the highest was found in the N3000-treated plots, with the notable exception for July. Similarly, the lowest respiration fluxes occurred in May and the highest in August.

\section{Discussion and Conclusions Above-ground carbon pools}

This study is one of the few to apply silvicultural thinning in Chinese arborvitae, warm-temperate plantations (Duan et al. 2010). The primary goal was to determine the consequences of thinning on carbon stocks

the N3000 treatment. The response of above-ground shrub biomass to thinning was different from that of tree biomass. Above-ground shrub biomass in N3000-treated and N4100treated plots was on average 2.0 times and 1.6 times higher than control plots, respectively.

Patterns in belowground coarse root biomass were similar to the above-ground tree biomass. The amount of fine roots decreased with thinning intensities but differences between treatments was not significant. Despite differences in the proportion of tree and shrub biomass among treatments, the and fluxes in Chinese arborvitae plantations.

Generally, thinning leads to a decrease in volume increment per hectare (Slodicak et al. 2005) and several studies have shown that thinning leads to decreased standing biomass per hectare (Hoover and Stout 2007, Campbell et al. 2009). Therefore, controls had the largest carbon pools. Thinning regimes significantly increased carbon pools from the understory. The magnitude of this response was dependent on residual stand density and thinning intensity. A high stand density will have limited light penetration and water availabil- 
Table 4. Comparison of soil respiration rate (Rs), soil temperature (Ts) and water moisture (Ms) (mean and S.D.) during the growing period in 2011.

\begin{tabular}{|c|c|c|c|c|c|c|}
\hline & & May 15-18 & Jun 25-28 & Jul 20-23 & Aug 13-15 & Sep 15-18 \\
\hline \multirow{3}{*}{$\operatorname{Rs}\left(\mu \mathrm{mol} \mathrm{CO} \mathrm{m}^{-2} \mathrm{~s}^{-1}\right)$} & Control & $1.12(0.06)$ & $1.92(0.09)$ & $2.92(0.21)$ & $5.59(0.32)$ & $2.50(0.26)$ \\
\hline & N4100 & $2.35(0.13)$ & $2.89(0.16)$ & $2.82(0.22)$ & $5.88(0.42)$ & $3.60(0.31)$ \\
\hline & N3000 & $3.23(0.26)$ & $3.89(0.28)$ & $3.47(0.33)$ & $7.90(0.49)$ & $4.08(0.33)$ \\
\hline \multirow[t]{3}{*}{$\operatorname{Ts}\left({ }^{\circ} \mathrm{C}\right)$} & Control & $17.31(1.52)$ & $19.20(1.29)$ & $21.07(0.99)$ & $24.49(1.32)$ & $15.33(1.41)$ \\
\hline & N4100 & $18.41(1.25)$ & $22.83(1.43)$ & $21.57(1.32)$ & $23.01(0.98)$ & $13.18(1.26)$ \\
\hline & N3000 & $22.73(1.32)$ & $23.13(1.39)$ & $23.26(1.20)$ & $25.10(1.22)$ & $14.21(0.96)$ \\
\hline \multirow[t]{3}{*}{ Ms (\%) } & Control & $5.73(0.03)$ & $7.57(0.02)$ & $6.79(0.04)$ & $9.40(0.07)$ & $6.52(0.06)$ \\
\hline & N4100 & $6.78(0.04)$ & $8.85(0.04)$ & $7.35(0.05)$ & $12.15(0.08)$ & $8.05(0.05)$ \\
\hline & N3000 & $9.10(0.05)$ & $9.66(0.03)$ & $9.47(0.04)$ & $14.41(0.05)$ & $9.91(0.06)$ \\
\hline
\end{tabular}

ity, confining growth and accumulation to the understory. Understory vegetation gave a greater proportion of biomass to foliage indicating that compensatory responses of undergrowth to thinning may have an important impact on the carbon sink (Campbell et al. 2009). The increase in shrub carbon pools after thinning was smaller than either the amount of tree mass removed or left behind. Changes in forest structure may affect carbon allocation.

\section{Litter}

With differences in above-ground biomass, it might be expected that there would be more litter in the control plots. However, differences between thinning treatments were not statistically significant (Fig. 2). Litter was approximately 0.78 t C ha-1 $\mathrm{a}^{-1}$ to $1.00 \mathrm{t} \mathrm{C} \mathrm{ha} \mathrm{a}^{-1} \mathrm{a}^{-1}$ in the different treatments which is minor compared to the litter of highly productive pine forests in Beijing of $2.34 \mathrm{t} \mathrm{C} \mathrm{ha}^{-1} \mathrm{a}^{-1}$ (Fang et al. 2007). Additionally, thinning had no effect on the production of litter. This is consistent with Slodicak et al. (2005), who found no differences between the amounts of litter in unthinned controls and thinned plots in even-aged Norway spruce.

\section{Soil}

Variations in soil carbon may be attributed to litter and/or the decomposition of root systems (Slodicak et al. 2005). In this study, decreased soil respiration and increased litter production in control plots increased soil carbon but there were no significant effects on soil carbon due to thinning. The difference in litter produced in control and N3000 plots was $0.22 \mathrm{t}$ $\mathrm{C} \mathrm{ha}^{-1} \mathrm{a}^{-1}$ and soil respiration averaged $1.70 \mu \mathrm{mol} \mathrm{CO}_{2} \mathrm{~m}^{-2} \mathrm{~s}$ ${ }^{1}$. Taking this difference over five months, the result is $6.40 \mathrm{t}$ $\mathrm{C} \mathrm{ha} \mathrm{a}^{-1} \mathrm{a}^{-1}$. Högberg et al. (2001) found that $50 \%$ of soil respiration was root respiration. The difference in heterotrophic respiration was $3.20 \mathrm{t} \mathrm{C} \mathrm{ha}^{-1} \mathrm{a}^{-1}$. Increased litter and lower heterotrophic respiration in the two treatments $\left(4.90 \mathrm{t} \mathrm{C} \mathrm{ha}^{-1}\right.$ $\mathrm{yr}^{-1}$ ) equals $8 \%$ of total soil carbon stocks in the control plots. Additionally, slash was removed after thinning. This indicates that changes in soil carbon stocks within a seven-year time frame may be too minor to detect.

\section{Soil respiration}

Average soil respiration varied between 1.12 and $7.90 \mu \mathrm{mol}$ $\mathrm{CO}_{2} \mathrm{~m}^{-2} \mathrm{~s}^{-1}$ during the growing period, typical of Chinese arborvitae (Yu et al. 2011). The apparent conservation of soil respiration across treatments is consistent with the findings of Vesala et al. (2005) and Campbell et al. (2009), who found that soil respiration was unaffected by thinning treatments in ponderosa pine (Pinus ponderosa P. Laws. ex Laws.) forests in the Sierra Nevada Mountains.

Previous research has reported increases in soil respiration after thinning (Gordon et al. 1987, Hendrickson et al. 1989). This may be affected by soil temperature, water content, undergrowth cover, tree root biomass and litter fall. All these will affect soil microbial respiration and root respiration. Soil temperature and moisture may explain temporal variation in soil respiration (Yu et al. 2011). Increased soil temperature (Ts) and soil moisture (Ms) may also enhance root growth of remaining trees, given that there is less below-ground competition for water and nutrients (Santantonio and Santantonio 1987, Van Lear et al. 2000) and photosynthetic rates (Gravatt et al. 1997, Peterson et al. 1997). Additionally, thinning increased above-ground growth. This increased root growth and photosynthesis in thinned forests will increase root respiration. Investigation of litter biomass showed no differences between treatments. Russell and Voroney (1998) also indicated the inability of soil organic matter and litter mass to explain soil $\mathrm{CO}_{2}$ fluxes in a study of boreal aspen (Populus tremuloides Michx.).

In conclusion, increased thinning in 22-year-old Chinese arborvitae plantations reduced above-ground tree carbon pools but increased shrub carbon stocks seven years after thinning. Increased forest floor carbon pools were also found but no significant effects due to thinning could be determined.

\section{Acknowledgments}

This work was supported by grants from the Special Research Funds for Fundamental Research at the Central Universities (No.BLJD200904), service for science and technologies in Beijing Forestry University (No.TD2011-08), the Beijing Education Committee's Project for the Development of Departments and Postgraduate Education (No.CXYBL20082010), the Forestry Service Industry (No.201004021), Popularization service for science and technologies in forestry ([2011] NO.44), Cooperation of experimental monitoring about forest health in China and America (2009DFA92900). 


\section{References}

Campbell, J.L., G. Alberti., J.G. Martin and B.E. Law. 2009. Carbon dynamics of a ponderosa pine plantation following a thinning treatment in the northern Sierra Nevada. For. Ecol. Manag. 257: 453-463.

Chen, L.Z., Q.L. Chenm, X.C. Bao, J.K. Ren, Y.G. Miao and Y.H. Hu. 1986. Study on the biomass of Platycladus orientalis in Beijing mountain area. Acta Phytoecologica Geobotanica Sinica. 10: 17-24. Coyea, M.R. and H.A. Margolis. 1994. The historical reconstruction of growth efficiency and its relationship to tree mortality in balsam fir ecosystem affected by spruce budworm. Can. J. For. Res. 24: 2208-2221.

Dore, S., T. E. Kolb, M. Montes-Helu, S.E. Eckert, B.W. Sullivan, B.A. Hungate, J.P. Kaye, S.C. Hart, G..W. Koch, and A. Finkral. 2010. Carbon and water fluxes from ponderosa pine forests disturbed by wildfire and thinning. Ecol. Appl. 20: 663-683.

Duan, J., L.Y. Ma, L.M. Jia, Z.K. Jia, N.N. Gong and W.R. Che. 2010. Effect of thinning on Platycladus orientalis plantation and the diversity of undergrowth vegetation. Acta Ecol. Sin. 30: 1431-1441. Fang, J.Y, G.H. Liu and B. Zhu. 2007. Carbon budgets of three temperate forest ecosystems in Dongling Mt., Beijing, China. Sci. China Ser. D. 50: 92-101.

Feng, Z.W., X.K. Wang and G. Wu. 1999. Ecology of production and productivity in China. Science Press. pp: 80-97.

Finkral, A. J. and A.M. Evans. 2008. Effects of a thinning treatment on carbon stocks in a northern Arizona ponderosa pine forest. For. Ecol. Manag. 255: 2743-2750.

Gordon, A.M., R.E. Schlenter and K. Van Cleve. 1987. Seasonal patterns of soil respiration and $\mathrm{CO}_{2}$ evolution following harvesting in the white spruce forests of interior Alaska. Can. J. For. Res. 17: 304-310.

Gravatt, D.A., J.L. Chambers and J.P. Barnett. 1997. Temporal and spatial patterns of net photosynthesis in 12-year-old loblolly pine five growing seasons after thinning. For. Ecol. Manag. 97(1): 73-83.

Hendrickson, O.Q., L. Chatarpaul and D. Burgess. 1989. Nutrient cycling following whole-tree and conventional harvest in northern mixed forest. Can. J. For. Res. 19(6): 725-735.

Högberg, P., A. Nordgren, N. Buchmann, A.F.S. Taylor, A. Ekblad, M.N. Högberg, G. Nyberg, M. Ottosson-Löfvenius and D.J. Read. 2001. Large-scale forest girdling shows that current photosynthesis drives soil respiration. Nature 411: 789-792.

Hoover, C. and S. Stout. 2007. The carbon consequences of thinning techniques: stand structure makes a difference. Can. J. For. Res. 105: 266-270.

Hudiburg, T., B.E. Law, D.P. Turner, J.L. Campbell, D.C. Donato and M. Duane. 2009. Carbon dynamics of Oregon and Northern California forests and potential land-based carbon storage. Ecol. Appl. 19: 163-80.
Hurteau, M.D., G.W. Koch, and B.A. Hungate. 2008. Carbon protection and fire risk reduction: toward a full accounting of forest carbon offsets. Front. Ecol. Environ. 6: 493-498.

Law, B.E., P.E. Thornton, J. Irvine, P.M. Anthoni and S. Vantuyl. 2001. Carbon storage and fluxes in ponderosa pine forests at different developmental stages. Global Change Biol. 7: 755-777.

Liu, X., W. Xiang and S. Wen. 1992. Influence of thinning on biomass production of different densities of Masson's pine forests. In X. Liu (ed.) Long-Term Forest Ecosystem Research. pp. 274-278. Chinese Forestry Press. Beijing.

McClaugherty, C.A., J.D. Aber and J.M. Melillo. 1982. The role of fine roots in the organic matter and nitrogen budgets of two forested ecosystems. Ecol. 63: 1481-1490.

Peterson, J.A., J.R, Seiler, J. Nowak, S.E. Ginn and R.E. Kreh. 1997. Growth and physiological responses of young loblolly pine stands to thinning. For. Sci. 43: 529-534.

Russell, C.A. and R.P. Voroney. 1998. Carbon dioxide efflux from the floor of a boreal aspen forest. I. Relationship to environmental variables and estimates of C respired. Can. J. Soil Sci. 78: 301-310.

Santantonio, D. and E. Santantonio. 1987. Effect of thinning on production and mortality of fine roots in a Pinus radiata plantation on a fertile site in New Zealand. Can. J. For. Res. 17(8): 919-928.

Slodicak, M., J. Novak and J.P. Skovsgaard. 2005. Wood production, litter fall and humus accumulation in a Czech thinning experiment in Norway spruce. For. Ecol. Manag. 209: 157-166.

State Forest Administration. 2007. The seventh national forest inventory in China. For. Res. Manag. 1: 1-8.

Tang X.L., G.Y. Zhou, X. Zhou, D.Z. Wen, Q.M. Zhang and G.C. Yi. 2003. Coarse woody debris in monsoon evergreen broad-leaved forests of Dinghushan nature reserve. Acta Phytoecologica Sinica 27: 484-489.

Valentini, R., G. Matteueel and A.J. Dolman. 2000. Respiration as the main determinant of carbon balance in European forests. Nature 404: 861-865.

Van Lear, D.H., P.R. Kapeluck and W.D. Carroll. 2000. Productivity of loblolly pine as affected by decomposing root systems. For. Ecol. Manag. 138(1): 435-443.

Vargas, R., E.B. Allen and M.F. Allen. 2009. Effects of vegetation thinning on above-and belowground carbon in a seasonally dry tropical forest in Mexico. Biotropica, 41: 302-311.

Vesala, T. et al. 2005. Effect of thinning on surface fluxes in a boreal forest. Global Biogeochem. Cycles. 19: 1-11.

Yu, X. et al. 2011. Response of Soil Respiration to Soil Temperature and Moisture in a 50-Year-Old Oriental Arborvitae Plantation in China. PLoS ONE 6(12): 31-34. 